\title{
一様部材断面積を有する平面トラスのトポロジー・節点位置同時最適化 SIMULTANEOUS OPTIMIZATION OF TOPOLOGY AND GEOMETRY OF PLANE TRUSSES WITH UNIFORM CROSS-SECTIONAL AREA
}

\author{
田川 浩*, 大崎 純** \\ Hiroshi TAGAWA and Makoto OHSAKI
}

\begin{abstract}
A procedure based on a simulated annealing method is presented for simultaneous optimization of topology and geometry of a plane truss with uniform cross-sectional area. A continuous topology transition model is introduced for simulating continuous transition between truss structures with different topologies. In order to improve convergence property of annealing, constraints on allowable nodal locations are considered and re-annealing procedures are introduced. In the examples, optimal solutions are found for cantilever-type and bridge-type plane trusses, and the effects of annealing schedule on optimal solutions are discussed.
\end{abstract}

Keywords : shape optimization, topology optimization, simulated annealing, plane truss 形状最適化，トポロジー最適化，シミュレーテッドアニーリング，平面トラス

\section{1. 序}

トラス構造物の形状最適化問題には,トポロジー最適化問題と節点 位置最適化問題がある。これらは通常別々の問題として扱われ、一般 にトポロジーと節点位置を同時に最適化するのは困難である"。前者 で用いられる ground structure method では, 多くの存在可能部材及び 節点からなるトラスから, 不要な部材を除去することにより最適なト ポロジーを得る2.3)。この方法では, 無限に多くの部材が存在可能であ るとしなければ最適節点位置は得られない。一方, 節点位置最適化問 題では, 与えられたトポロジー下で, 節点座標を設計変数として数理

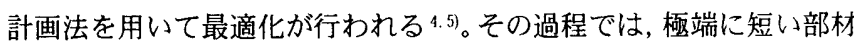
あるいは近接する平行な複数の部材が存在することを防ぐため節点座 標に対し上下限值が与えられており,近接する節点及び部材の一部を 取り除いてトラスのトポロジーを変更することは極めて困難である。

均質化法 ${ }^{6}$ は, トポロジーと形状を同時に最適化するために有効で ある。しかし, 板要素とトラスを構成する直線形状の棒材には大きな 違いがあり, 部材断面積が一様であるという条件を設けたトラスの形 状最適化問題に均質化法を適用するのは困難である。

近年, トラス形状最適化問題に対し, 遺伝的アルゴリズム $(\mathrm{GA})$ やシ ミュレーデッドアニーリング(SA)等のヒューリスティクス(発見的手 法）を使用して近似最適解を求める手法が多く提案されている7 191。 単純な基本トラスを初期解とし，与えた規則に従って部材を付加ある いは除去していくことにより最適なトポロジーを得る手法も提案され ている15.16)。しかし, これらの手法では, トポロジーの変化や部材の 付加・除去を行うための経験的・発見的アルゴリズムが必要であり，
そのため対象構造物の規模が大きくなると計算負荷が大きくなるとい う問題がある。

Ohsaki ${ }^{77}$ は, シグモイド関数を用いた連続的トポロジー変化モデル を規則的平面トラスに対して構築し, 数理計画法によりトポロジーと 節点位置を同時に最適化する手法を提案した。連続的トポロジー変化 モデルは, 節点数, 部材数および節点間の接続関係など, 初期に与え た情報を全く変更することなくトポロジーを連続的に変化させるため のモデルである。このモデルを適用すれば, 最適化の過程で節点座標 のみを設計パラメ夕とすればよく計算負荷は小さくなる。筆者らは, このモデルと遺伝的アルゴリズムを併用した手法を提案している ${ }^{18 \%}$ 。 しかし对象は規則的平面トラスに限定されていた。

本研究では, 規則性を持たない平面トラスに対して, トポロジーと 節点位置を同時に最適化するための手法の構築を目的としている。対 象とするトラスは, 部材断面積が全部材に対して一様であるとする。 この制約は実用性の観点から重要である。この制約を考虑することに よる困難点は, 上述した連続的トポロジー変化モデルの適用により合 理的に回避できることが文献 17)に示されている。

本論文では, まず, 本研究で想定する最適化問題の特徵について述 べる。規則性のない平面トラスに適用できる連続的トポロジ一変化モ デルを示し, 最適化アルゴリズムに対するSA 法の適用について述べ る。また, 最適解への収束性を高めるために導入した種々の方法を紹 介する。例題を通じて, SA 法における温度管理が収束解に及ぼす影 響, 最適化過程のトラス形状の変化, 再アニーリングの有効性等につ いて述べるとともに，本手法の有効性を示す。

\footnotetext{
注）本論文の一部は既に文献26)に発表している。

$*$ 京都大学大学院工学研究科建築学専攻 助手・工修

** 京都大学大学院工学研究科建築学専攻 助教授 $\cdot$ 博士 (工学)
}

Research Assoc., Dept. of Archi. and Architectural Systems,

Kyoto University, M. Eng.

Assoc. Prof., Dept. of Archi. and Architectural Systems, Kyoto University, Dr. Eng. 


\section{2. 本研究で対象とする最適化問題の特徽}

\section{1 トポロジー・節点位置同時最適化}

荷重の作用する節点と支点の位置が定められたトラスの形状最適化 を考える。例えば, 図 1 (a)に示す片持ち梁型トラスでは支点間距離 $H$, 荷重の作用する節点と支点の距離Wは固定される。部材の断面積は一 定値 $A$ をとるものとする。節点荷重べクトルを $\boldsymbol{P}$, 系剛性行列を $\boldsymbol{K}$, 変 位ベクトルを $\boldsymbol{U}$ とすると剛性方程式は次式となる。

$$
\boldsymbol{K} \boldsymbol{U}=\boldsymbol{P}
$$

変位制約条件下で部材体積を最小化する最適化問題は次のように書 ける。

$$
\begin{aligned}
& \min \sum_{i=1}^{N} L_{i} A_{i} \\
& \text { subject to }\left|U_{j}\right| \leq \bar{U}_{j} \quad(j=1,2, \cdots, M)
\end{aligned}
$$

ここに,

$$
\begin{array}{ll}
N & : \text { 部材数 } \\
L_{i} & : \text { 第 } i \text { 部材の部材長 } \\
A_{i} & : \text { 第 } i \text { 部材の断面積 }(0 \text { または } A) \\
M & : \text { 変位の自由度数 } \\
U_{j} & : \text { 変位ベクトル } U \text { の第 } j \text { 成分 } \\
\bar{U}_{j} & :\left|U_{j}\right| \text { の指定上限値 }
\end{array}
$$

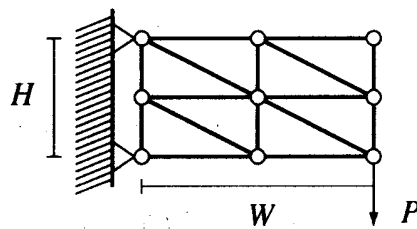

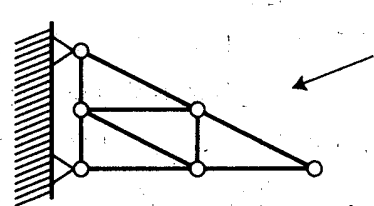

(b) (a)
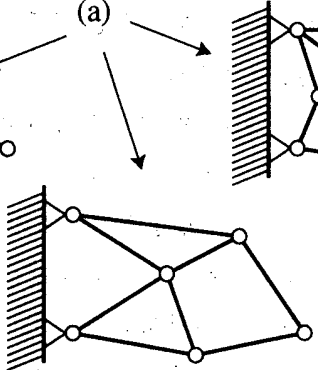

(d)

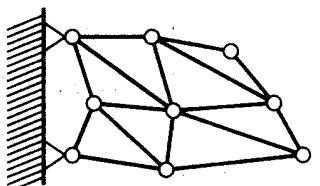

(c)
図 1 トラス形状最適化問題の分類; (a) 初期構造物, (b) 卜ポロジー 最適化, (c) 節点位置最適化, (d) トポロジー・節点位置同時最適化

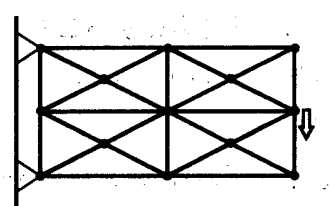

(a) 初期解 (トラス)

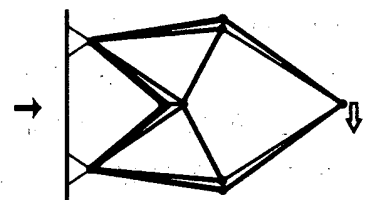

(b) 最適解

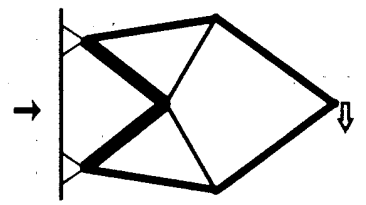

(c)設計解形状
(I) 数理計画法により得られる最適解において近接する部材を結合する方法

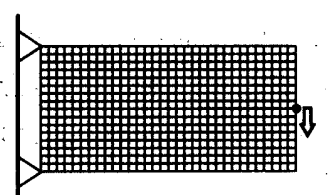

(a) 初期解 (平板)
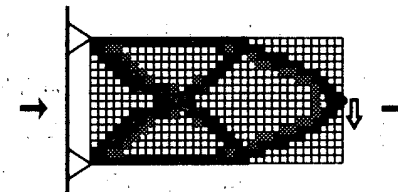

(b) 最適解

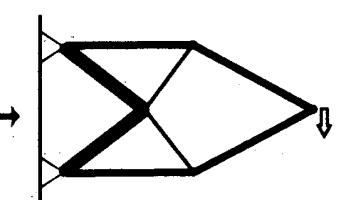

(c) 設計解形状
(II)均質化法により得られる最適解と等価なトラスを生成する方法

図 2 平面トラスのトポロジー・節点位置同時最適化のため方法（模式図）
本問題では, 存在する部材の断面積を, 全トラスにわたって一定の $A$ としており, $A$ は $\left|U_{j}\right|$ が最大となる変位成分において $\left|U_{j}\right|=\bar{U}_{j}$ と なるように決定する。

この問題に対して,トポロジー最適化問題では, 図 1 (b)に示すよう に節点位置を固定し, 部材を除去することにより最適解を求める。一 方, 節点位置最適化問題では, 図 1 (c)に示すようにトポロジーを固定 し，節点位置を移動させることにより最適解を求める。それに対し， 本研究で考えるトポロジー・節点位置同時最適化問題では, 図 1 (d)に 示すように節点位置およびトポロジーのいずれも固定することなく直 接最適解を求める。

\section{2 部材断面㮴が全部材一様であるという制約の導入}

実用的なトラス構造物では, 各部材断面積が任意の值をとることが 許容されない場合が多い。それは，各部材がそれぞれ異なる断面積を 有すると，たとえ総体積が小さくても建設コストが高くなる等の理由 による。そこで本研究では部材断面積が全部材一様であるという制約 を導入する。任意の正の值をとることが可能な場合のトラス形状最適 化問題では, 図 2 (I)に示すように数理計画法による最適化の結果得ら れたトラス構造物 (同(b)図)において近接する部材をまとめて 1 つの 部材とし設計解（同(c)図）とする方法，あるいは図 2 (II)に示すよう に均質化法で得られた最適解 (同(b)図) と等価なトラスを生成し設計 解 (同(c)図) とする方法 ${ }^{19)}$ も可能である。しかし，これらの手法では， 全部材の断面積が一様であるという制約を直接的に考虑することはで きない。したがって，この制約を導入することにより最適解を求める ことはより困難となる。

3. 規則性のないトラス構造物に対する連続的トポロジー变化モテル 連続的トポロジー変化モデル円は, 節点数, 部材数および節点間の 接続関係など,初期に与えた情報を全く変更することなくトポロジー を連続的に変化させていくためのモデルである。このモデルを本研究 で適用することの長所は 2 つある1つはトポロジーを設計変数とす る必要がなくなり計算負荷が大幅に軽減されること,もう 1 つは全部

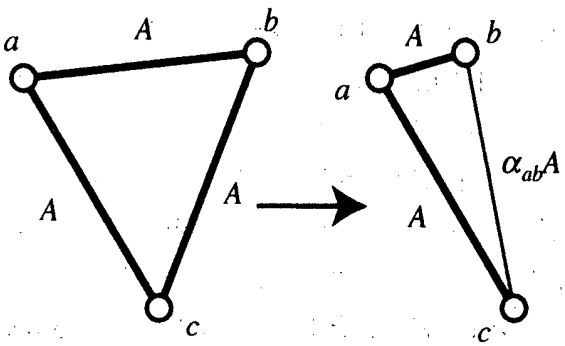

(a)

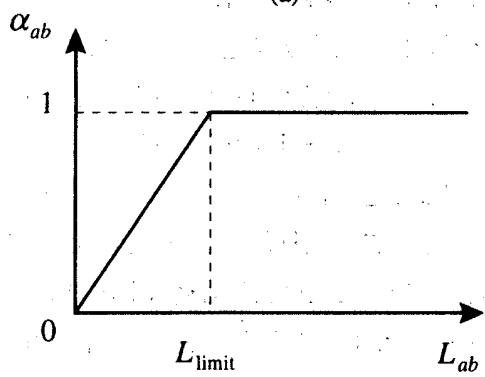

(b)

図 3 連続的卜ポロジー変化モデルの基本概念; (a)トラス ユニット（節点 $b$ が節点 $a$ に接近），(b) $\alpha_{a b}-L_{a b}$ 関係曲線 


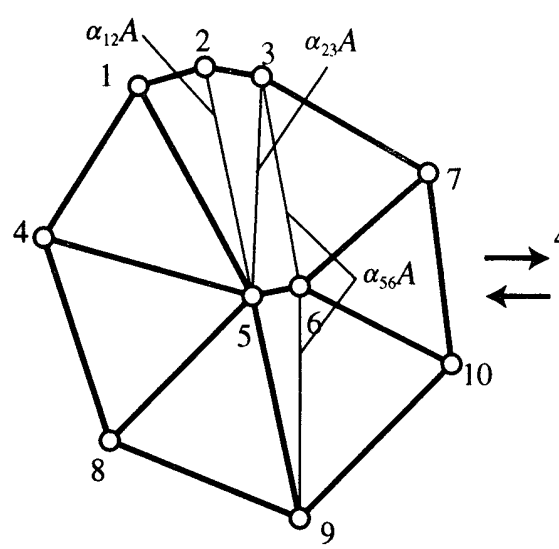

(a) 19 部材トラス

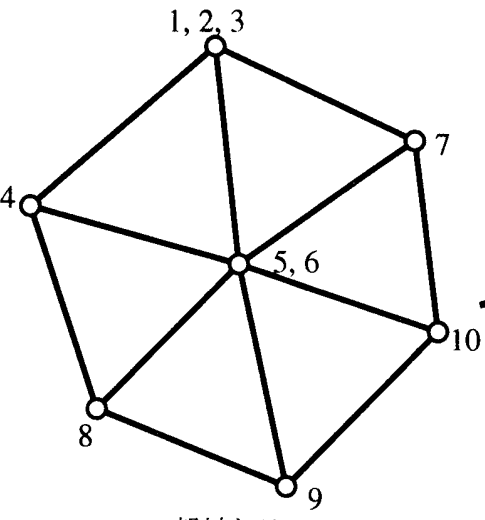

(b) 12 部材トラス

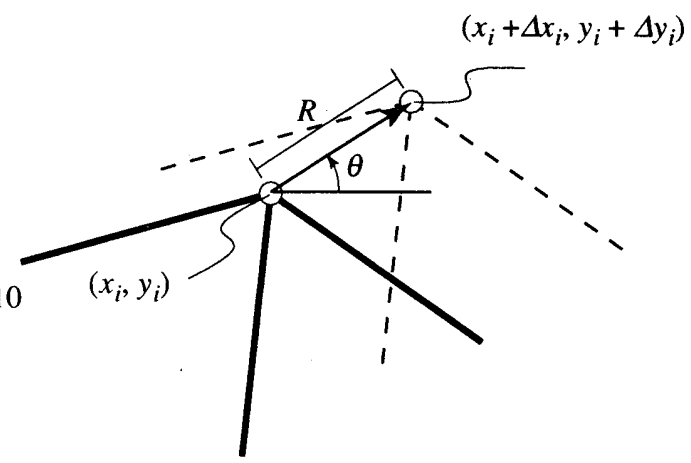

図 5 節点移動による近傍解の生成

材が一様断面積を有するという制約を合理的に考慮できる点である。 本章では,規則性のない平面トラスに対する連続的トポロジー変化モ デルについて説明する。

\section{1 基本概念}

まず，図3(a)に示す三角形トラスユニットを用いてモデルの基本概 念を述べる。節点 $k$ および節点 $l$ をつなぐ部材（以下，部材 $k l$ と呼ぶ） の部材長を $L_{k l}$ で表す。図3(a)左図では $L_{a b}, L_{b c}, L_{a c}$ のいずれも十分 大きく, この場合断面積は全て $A$ である。次に, 同右図のように節点 $b$ が節点 $a$ の近くに移動した場合を考える。ここで, 図 3(b)に示す係 数 $\alpha_{a b}$ を導入する。これは, $L_{a b}$ の関数であり, 次式で表される。

$$
\begin{cases}\alpha_{a b}=\frac{L_{a b}}{L_{\text {limit }}} & \left(0 \leq L_{a b}<L_{\text {limit }}\right) \\ \alpha_{a b}=1 & \left(L_{\text {limit }} \leq L_{a b}\right)\end{cases}
$$

ここに, $L_{\text {limit }}$ は限界部材長である。係数 $\alpha_{a b}$ は, 部材 $b c$ あるいは部材 $a c$ のいずれか一方の断面積に対する係数である。図 3(a)では, $L_{a b}$ が $L_{\text {limit }}$ より短くなっており, 部材 $a c$ の断面積は $A$ を維持し, 部材 $b c$ の 断面積が減じられ $\alpha_{a b} A$ となっている。以下, 1 つの部材が $L_{\text {limit }}$ より 短くなっているトラスユニットにおいて, $L_{\text {limit }}$ より長い2つの部材を 互いに“対部材”と呼ぶ（部材 $a c$ と部材 $b c$ は互いに“対部材”であ る)。節点 $b$ が節点 $a$ に一致すると, 部材 $b c$ の断面積は 0 となり断面 積が $A$ である部材 $a c$ のみが存在することになる。

\section{2 平面トラス桡造物への適用}

このモデルを複数のトラスユニットで構成されるトラス構造物に拡 張する。図 4 (a)では, 部材 12 , 部材 23 および部材 56 の部材長が限界 部材長 $L_{\text {limit }}$ より短くなっている。節点 $5,6,9$ で構成されるトラスユ ニットについては, 部材 59 あるいは部材 69 のいずれの断面積が減じ られてもよい。ところが, 節点 $1,2,3,6,5$ で囲まれた領域には, トラス ユニットが 3 個隣接して存在しており,断面積を減ずる部材を選択す るには適当なアルゴリズムが必要となる。これを以下に示す。

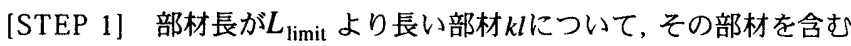
トラスユニットの中で部材長が $L_{\text {limit }}$ より短い部材の個数 $S_{k l}$ を求める (図 4 (a)では, $S_{15}=1, S_{25}=2, S_{35}=2, S_{36}=1$ である)。

[STEP 2] $S_{k l}=1$ の部材（部材 15 および部材 36）のどちらか一方の 部材の断面積を $A$ とし(図では部材 15 の断面積を $A$ とした), その“対
部材”の断面積を減少させる（部材 25 の断面積を減ずる）。 [STEP 3] 前 STEP で断面積を減少させた部材 $p q$ について, $S_{p q}=1$ であれば終了, $S_{p q}=2$ であればその部材の “対部材” のうちで, 断面 積值が未定の方の断面積を減少させる。

[STEP 4] STEP3に戻る。

なお, [STEP 2] で, $S_{k l}=1$ の部材のうち断面積を $A$ とする部材の選 択方法により最適化の過程は変化する。しかし, 後に 6.2 節で示す方 法等を用いれば, 最終的に得られるトラスでは $L_{\text {limit }}$ より短い部材は 極めて短くなるため，選択方法によらずトラスは同一のものとなる。 図4(a)の19部材トラスにおいて節点 $1,2,3$ およ゙節点 5,6 がそれぞれ 一致すると，同(b)図の 12 部材トラスへ変化する。なお，連続的トポ ロジー変化モデルでは，見かけ上トポロジーが変化するのみであり， 実際にトポロジーは変化しない。すなわち最適化の過程において節点 間の接続関係等は変わらないため, 図4(b)の12部材トラスにおいて節 点 $1,2,3$ および節点 5,6 が分離し，再び 19 部材トラスに戻ることも可 能である。ただし， 6.3 節に示す再アニーリングの開始時において一 度結合された節点同士は分離することはできない。

\section{4. ピン接合トラスの最適化における問題点および解決法 ${ }^{17)}$}

前節に示したトポロジー変化モデルをピン接合トラスに適用する際 に生じる問題点は，次の通りである。

（1）ピン接合トラスでは, 近接する節点間の距離が微小であっても, 荷重作用時はそれらの相対変位が微小ではなく有限な值をとる場合が あるため,トポロジーを連続的に変化させても力学的特性が不連続と なる場合がある。

（2）部材長が極めて小さい部材が存在すると剛性行列が非正則にな ることがある。

上記問題点を解決するため, (1) についてはピン接合トラスを剛 接合卜ラスに置き換える。ここで, 断面 2 次半径 $\gamma$ は全部材に対して 一定で, 十分小さいものとする。ピン接合トラスと剛接合トラスを比 較したとき, 部材内の局所的変形状態は全く異なるが, 部材の曲げ剛 性が十分小さい場合には, 部材の軸方向変形および各節点の変位量は ほぼ等しくなる。（2）については，部材長に関して最小制限值 $D$ を 与え, 極端に短い部材が存在しないようにする。Dの值は前節に示し た $L_{\text {limit }}$ の值よりも十分小さい值である。 


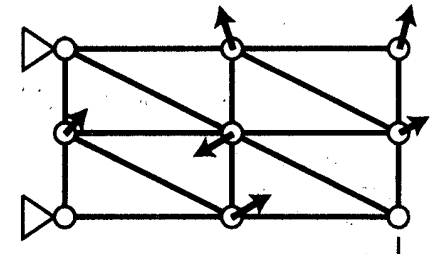

(a) 全節点を移動

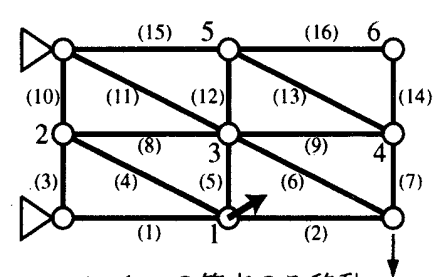

(b) 1 つの節点のみ移動
図 6 状態生成時における節点座標の移動方法

\section{5. シミュレーテッドアニーリンク法による最適化}

シミュレーテッドアニーリング (SA) 法 ${ }^{20)}$ は, 熱統計力学的現象に 着想を得た最適化手法である。その特徵は温度概念を用いた確率的ゆ らぎの導入と温度制御により, 多数の局所的最適解から抜け出し, 大 域的最適解の近似解 (以下, 単に最適解と呼ぶ) が求められることで ある。以下に本研究で用いた方法を示す。

\section{1 状態生成}

状態生成とは，現設計解の近傍でランダムに設計解（以下，近傍解 と呼ぶ) を生成することである。本問題では, 以下に示す節点座標移 動と部材の強制的除去の 2 通りの方法で近傍解を生成する。

\subsection{1 節点座標移動}

図 5 に示すように第 $i$ 節点の座標を, $\left(x_{i}, y_{i}\right) \rightarrow\left(x_{i}+\Delta x_{i}, y_{i}+\Delta y_{i}\right)$ と移動させることにより近傍解を生成する。ここに,

$$
\left\{\begin{array}{l}
\Delta x_{i}=R \cos \theta \\
\Delta y_{i}=R \sin \theta
\end{array}\right.
$$

であり， $\theta$ およびRは $(0 \leq \theta<2 \pi),\left(0 \leq R<R_{\max }\right)$ の区間内で,それ ぞれ一様乱数を発生させ求める。1 度の状態生成時における節点移動 には, 図6(a),(b)に示すように，次の 2 通りが考えられる。

(a) 全節点に対し個別に式(5)を適用し，各々同時に移動させる方法

(b) 着目する1つの節点の文移動させ,付した番号に従って着目する 節点を変更していく方法。(図6(b)では，着目する節点が 1 から 始まり 6 に達すると再び 1 に戻る。)

ここでは次の点を考虑して, (b)の方法を適用する。すなわち, 節点移 動により生成される近傍解は 5.2 節に示す置換確率で新設計解として 置換されるが, アニーリングの過程 (特に後半)において, 既に最適 解に対し良好な位置にある節点の移動により生成される近傍解は置換 され難く,最適解へ収束するためにはさらに移動すべきである節点の 移動により生成される近傍解は置換され易いという効果が, (a)の方法 では期待できないのに対し(b)の方法では期待できる。

\subsection{2 部材の強制的䟻去}

3 章で示した連続的トポロジー変化モデルは, 3 角形トラスユニッ トに対するモデルであり， 7.2 節に示す例題 2 のように四角形ユニッッ トを有するトポロジーを得ることは不可能である。そこで; 四角形ユ ニットの存在を許容するトラス構造物の場合には，“第 $i$ 部材の存在を 表す変数 $e_{i}=\{0,1\}$ を導入する。連続的トポロジー変化モデルにお いて断面積が減じられない部材 (3.2節で示した[STEP 2]において断面 積を $A$ とする部材) の断面積に対して, $e_{i}=0$ のとき $A_{i}=0$ (数值解析 上は $A / 10000$ とする),$e_{i}=1$ のとき $A_{i}=A$ とする。 $e_{i}$ の值は節点座標 と同様にアニーリングの過程で確率的に更新していく。1 度の状態生 成時における $e_{i}$ の值の変更は, 着目する 1 つの部材でのみ行い, 付し た番号に従って着目する部材を変更していく。図6(b)のトラスでは,

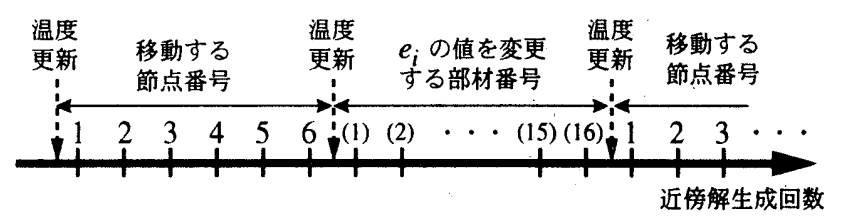

図 7 状態生成時に着目する節点番号·部材番号と近傍解生成回数の 関倸および温度更新時刻（図 6(b)のトラスの例）

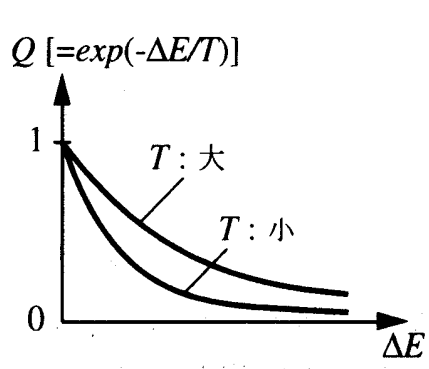

図 $8 Q \sim \Delta E$ 関係 $(\Delta E>0)$

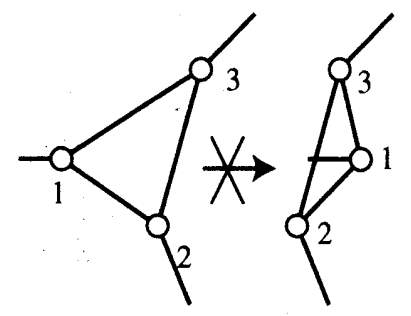

図 9 節点移動の拘束
着目する部材が(1)から始まり(16)に達すると再び(1)に戻る。

図 7に，図6(b)のトラス構造物について，近傍解生成回数之状態生 成時に着目する節点の番号あるいは部材の番号との関俰を示す。節点 座標移動と $e_{i}$ の值の更新は同時には行わず交互に行う。

\section{2 状態变化}

状態変化とは，5.1節で述べた状態生成により得られた近傍解を新 設計解として確率的に置換することである。近傍解の置換確率 $Q$ に は，次式で表されるメトロポリス基準21を用いる。

$$
Q=\min [1, \exp (-\Delta E / T)]
$$

ここに,

$$
\Delta E=E^{\prime}-E
$$

ただし, $E$ および $E^{\prime}$ は現設計解および近傍解の総体積, $T$ は正の值を 持つ変数であり 5.3 節で詳述する。 $\Delta E$ が負, 即ち生成した近傍解の体 積が現設計解の体積より小さい場合には $Q=1$, 即ち無条件で置換す る。一方, $\Delta E$ が正, 即ち生成した近傍解の体積が現設計解の体樌よ り大きい場合には，図 8 に示すように，同じ $T$ の值に対しては $\Delta E$ の 值が小さいほど置換確率は大きくなり，同じ $\Delta E$ の值に対しては $T$ の 值が大きいほど置換確率は大きくなる。

以下では, ステップ数を近傍解が新設計解として監換された回数と する。この場合，近傍解生成回数はステップ数と同じか; あるいは大 きい値となる。

\section{3 徐冷}

アニーリングの過程で温度を下げる操作を徐泠という。具体的には 式(6)中の変数 $T$ の值を減少させていく操作である。以下, 変数 $T$ を温 度と呼ぶ。SA 法では, 物質を徐冷しでエネルギーの低い状態を作る 物理プロセスにならって,最初のうちは温度を高く設定して大域的に 状態推移を行わせ, 温度を徐々に下げていくことにより, '評価の高い 解の近傍での探索を重点化して最適化問題の解を得ようとする。ここ では，温度管理に指数型アニーリング22)を適用する。すなわち，第 $k$ 番目の温度を $T_{k}$ としたとき, 第 $k+1$ 番の温度を次式から求める。

$$
T_{k+1}=\eta T_{k}
$$

$\eta$ の值として $0.95 \sim 0.97$ の值を与える。なお, 温度更新は, 図 7 に示 したように状態生成時に着目する節点番号あるいは部材番号がそれぞ れー巡した時点で行うことにする。 


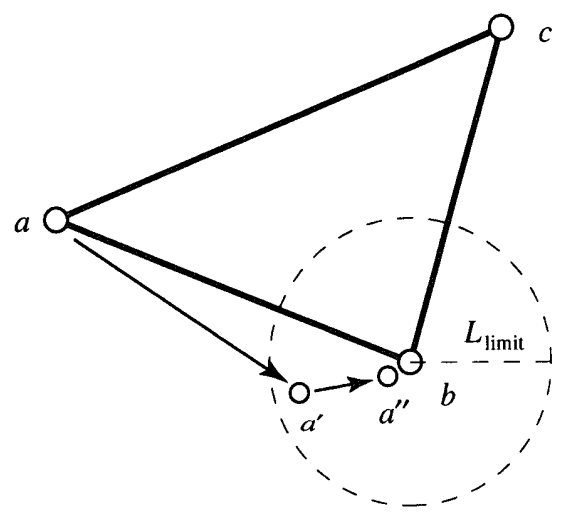

図 10 節点の強制移動

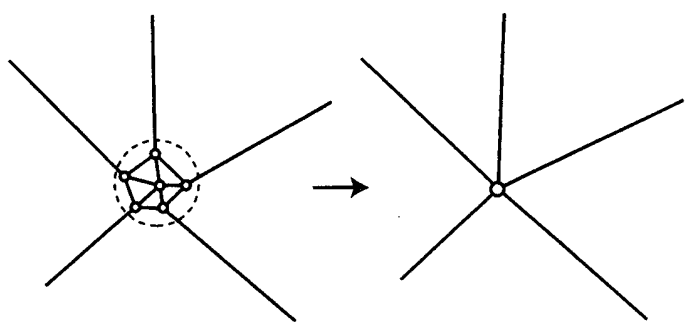

図 11 再アニーリング開始時における節点の結合

\section{4 アニーリングの終了条件}

アニーリングの終了（停止と呼ぶこともある）条件には種々のもの が提案されている22)が，ここでは温度 Tが指定值まで低下した時点， あるいは近傍解の生成回数が指定回数に達した時点の早い方とする。 アニーリングの最終段階では, 設計解が最適解に近づいていること, 温度が低くなっていることから, 近傍解が新設計解として固換される 割合が非常に小さくなり,そのため近傍解生成回数がステップ数と比 べて急激に増大するという現象が見られる。上述したアニーリング終 了条件の後者の方はこの性質に着目したものである。

\section{6. 収束性を高めるための方法}

前節までに示した方法を複数の最適化問題に適用したところ,以下 に示す条件等を考虑することにより, 最適解への収束性が向上した。

\section{1 節点移動の拘束}

5.1.1項に示した節点座標移動に際して, 各トラスユニットを構成す る三角形の符号付き面積の符号が変化しない，という拘束を与える。 符号付き面積は, 三角形の頂点の節点座標が $\left(x_{1}, y_{1}\right),\left(x_{2}, y_{2}\right),\left(x_{3}, y_{3}\right)$ の とき, $\left\{x_{1}\left(y_{2}-y_{3}\right)+x_{2}\left(y_{3}-y_{1}\right)+x_{3}\left(y_{1}-y_{2}\right)\right\} / 2$ により求められる。図 9 の左図に おいて, 三角形123の符号付き面積が正であれば, 右図では負となる。 したがって，符号付き面積の符号に関する制約を与えることにより， 交差する部材が現れるのを防止できる。なお, 三角形の少なくとも 1 つの辺の長さが $L_{\text {limit }}$ よりも短い場合この条件は考慮しない。交差す る部材の存在を許容する問題においては，この拘束は不要である。

\section{2 節点の強制移動}

本研究で考えている最適化問題では,最終的に得られる解において 部材断面積は 0 あるいは $A$ でなければならない。しかし, 部材長が 0 と限界部材長 $L_{\text {limit }}$ の中間の值をとる部材が存在する場合には, 断面 積が 0 から Aの中間の值をとる部材が存在することになる。そこで, 図10に示すように, ある節点を移動させたとき $\left(a \rightarrow a^{\prime}\right)$, その節点 を含む部材の部材長が $L_{\text {limit }}$ よりも短くなる場合, その部材長が十分 短くなる（4章に示した最小部材長制限值程度）座標まで節点を強制
的に移動させる $\left(a^{\prime} \rightarrow a^{\prime \prime}\right)$ 。同時に, 断面積が減じられる部材の断面 積を強制的に $A / 10000$ とする。

\section{3 節点の結合および再アニーリング}

多様なトポロジーの最適トラスを得ることを可能とするためには， 初期解における節点数・部材数を十分多くする必要がある。この場 合, 実際の最適解に比べて節点数が多い局所最適解に収束する可能性 が高くなる。そこで，一度アニーリングを行って得られたトラスにお いて, 例えば図11左図に示す破線の円で囲まれた節点群, すなわち節 点間の部材長がある指定した值より短い部材で接続される複数の節点 を図11右図に示すように結合し 1 つの節点と考える。節点結合の結果 得られたトラスを初期解として再びアニーリングを行う。このように アニーリングの結果得られた解を初期解として再びアニーリングを行 う手法を再アニーリングと呼ぶ23》。一度結合された節点群は再び分離 されることはない。節点結合・再アニーリングを繰り返し，節点結合 操作時に節点数の減少がなくなれば最適化プロセスを終了する。各再 アニーリングにおける終了条件は 5.4 節に示したものと同じとする。 ただし，近傍解生成回数は各再アニーリング開始時に0に戻す。

なお, 上述したように節点結合の基準は節点間の部材長が指定値よ り短いことであるが，6.2 節に示した “節点の強制移動”を適用する 場合には, 全部材は, $L_{\text {limit }}$ より長い部材および部材長が最小部材長制 限值程度の部材の 2 つに分類され，後者の部材長を持つ部材で接続さ れる節点同士を結合することになる。この場合, 数值解析上重要なこ とは, 初期に与えた節点間の接続関倸を節点結合に応じて変更する必 要はないことである。すなわち, 再アニーリングの過程において, 状 態生成時に節点座標を移動させる際には, 結合すると想定した節点相 互の位置関係を維持しつつ各節点座標を平行移動すればよい。よつ て,節点間の接続関係など初期に与えた情報を再アニーリング時にも 継続して用いることができる。

\section{7. 例題}

構築した手法の適用例を 4 例示す。部材断面積は全部材一様である とし，部材の交差は許容しない。アニーリングの終了条件は，近傍解 生成回数が10000回に達した時点あるいは温度が 5 以下になる時点の 早い方とする。例題 1 〜 4 にいて次の值は共通のものを用いる。節 点変位指定上限值 $\bar{U}_{j}=1.0 \mathrm{~cm}, 3.1$ 節に示した限界部材長 $L_{\text {limit }}=20 \mathrm{~cm}$, 部材の断面 2 次半径 $\gamma=3.1623 \mathrm{~cm}$, 最小部材長制限值 $D=0.1 \mathrm{~cm}$ およ びヤング倸数 $E=205.8 \mathrm{GPa}$ 。 5.1 .2 項で述べた部材の強制的除去は例 題 2 でのみ考虑する。すなわち，例題 2 では 4 角形トラスユニットの 存在を許容する。再アニーリングは例題 2,3 および 4 で行う。

\section{1 例題 $1:$ 片持ち梁型トラス(Type-1)}

初期解として図12に示す片持ち梁型トラス(Type-1)の形状最適化を 考える。W=300 cm, $H=150 \mathrm{~cm}, P=980 \mathrm{kN}, R_{\max }=80 \mathrm{~cm}$ である。表 1 に示す，初期温度・温度更新係数が異なる 4 ケースの結果を示す。

図13に総体積の推移を1000ステップまで示す。既に述べたように， ステップ数は解の更新回数に対応しており,近傍解生成回数とは異な る。第 1000 ステップにおける総体積を比較すると, Case A が最も小 さくなっている。Case Aに対し, Case Bは初期温度が低く, 逆にCase Cでは高く，それぞれCase Aより悪い結果となっている。一方, Case Dの初期温度はCase $\mathrm{A}$ と等しいが, 温度更新係数が小さく, すなわち 徐冷が速く, Case A よりも悪い結果となっている。図 14 に各ケース 


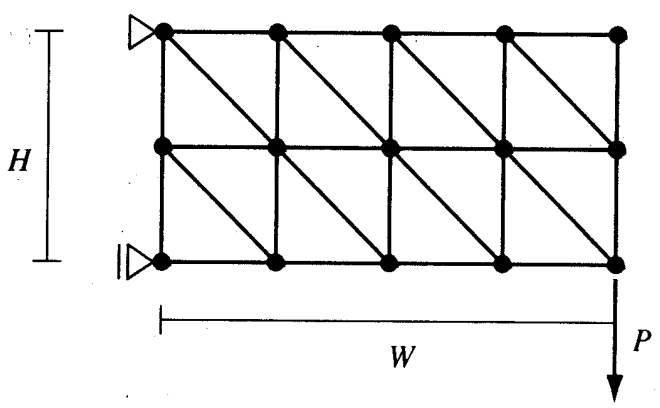

図 12 片持ち梁型トラス (Type-1)

表 1 初期温度 - 温度更新係数

\begin{tabular}{|c|c|c|}
\hline & $\begin{array}{c}\text { Initial } \\
\text { Temp. } ; T_{0}\end{array}$ & $\begin{array}{c}\text { Temp. update } \\
\text { coef. ; } \eta\end{array}$ \\
\hline Case A & 3000 & 0.97 \\
\hline Case B & 1500 & 0.97 \\
\hline Case C & 6000 & 0.97 \\
\hline Case D & 3000 & 0.95 \\
\hline
\end{tabular}

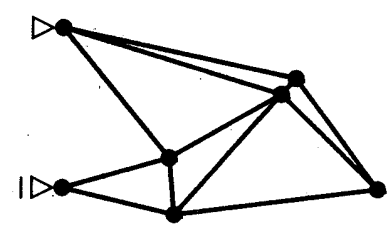

Volume $=68928.5 \mathrm{~cm}^{3}$ (a) Case $\mathrm{A}$

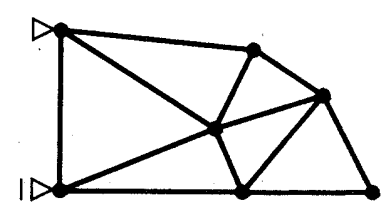

Volume $=81708.4 \mathrm{~cm}^{3}$

(b) Case B

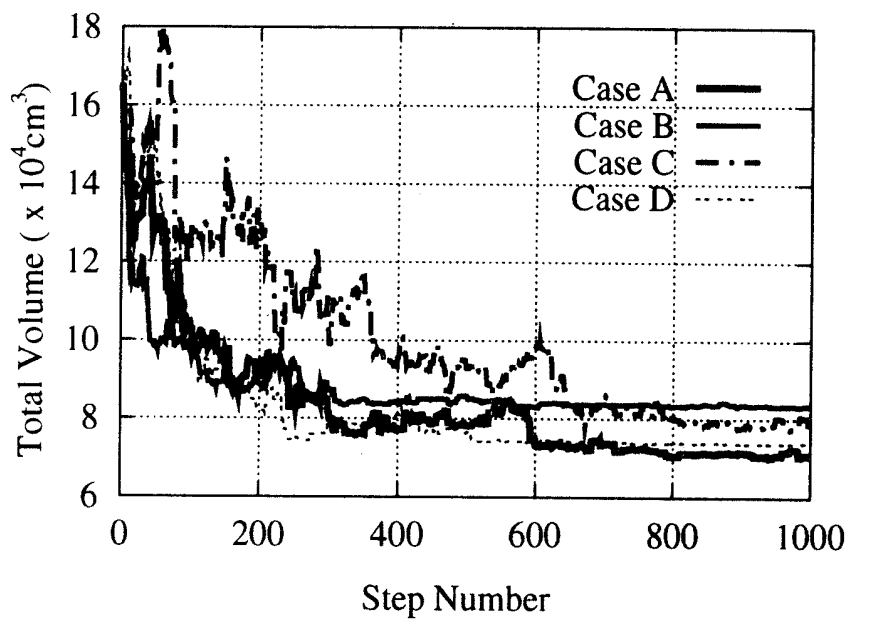

図 13 総体積の推移

図 14 最終形状および総体積の比較

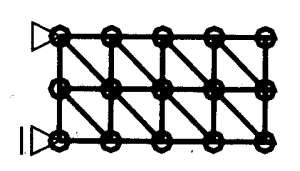

Step $=0$

Volume $=163720$

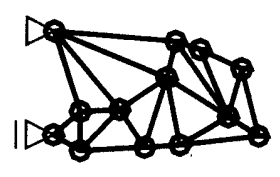

Step $=100$

Volume $=102610$

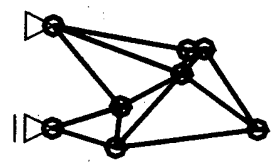

Step $=700$

Volume $=73740$

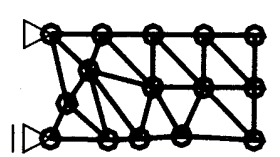

Step $=5$

Volume $=145030$

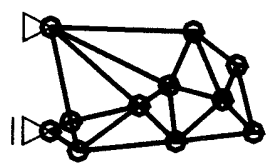

Step $=150$

Volume $=96480$

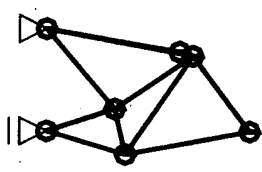

Step $=850$

Volume $=71250$

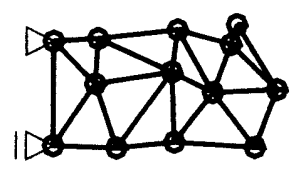

$\begin{aligned} \text { Step } & =20 \\ \text { Volume } & =131140\end{aligned}$

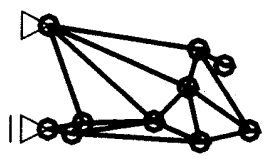

Step $=250$

Volume $=85640$

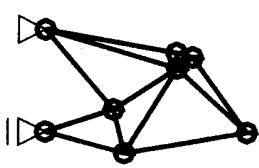

Step $=1000$

Volume $=70730$

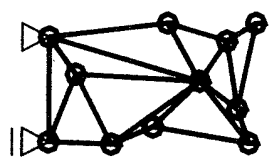

Step $=45$

Volume $=133950$

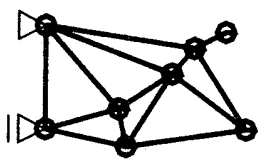

Step $=400$

Volume $=77290$

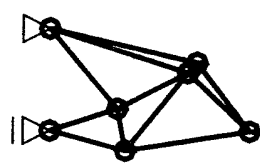

Step $=1200$

Volume $=69860$

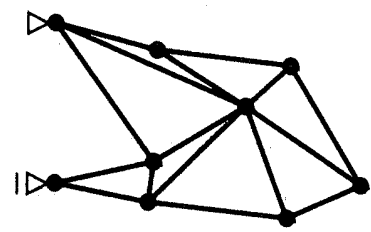

Volume $=73270.3 \mathrm{~cm}^{3}$

(d) Case D

図 15 アニーリング過程におけるトラス形状の推移 (Case A) 


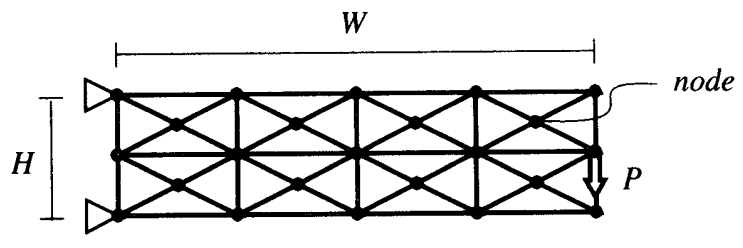

（a）初期形状（節点数 23）: Volume $=138146 \mathrm{~cm}^{3}$

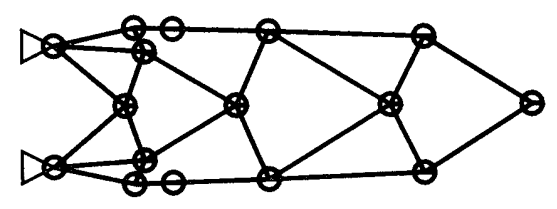

(b) 第 1 収束解（節点数 16）: Volume $=54471 \mathrm{~cm}^{3}$

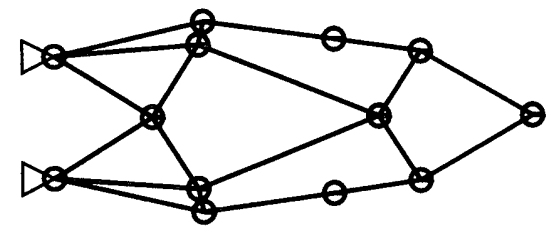

(c) 第 2 収束解（節点数 13）: Volume $=51775 \mathrm{~cm}^{3}$

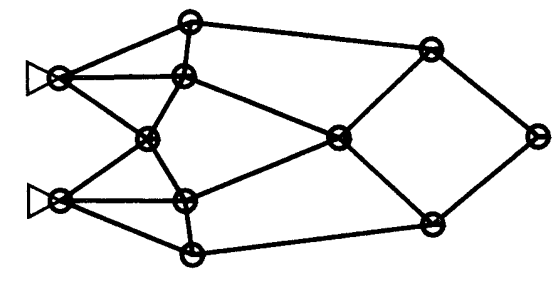

(d) 第 3 収束解（節点数 11）: Volume $=51206 \mathrm{~cm}^{3}$

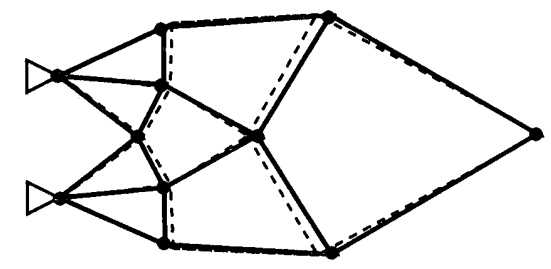

（e）最終収束解（節点数 11）: Volume $=48411 \mathrm{~cm}^{3}$ （破線は準ニュートン法による最適解 : Volume $=48128 \mathrm{~cm}^{3}$ )

図 16 片持ち梁型平面トラス (Type-2)

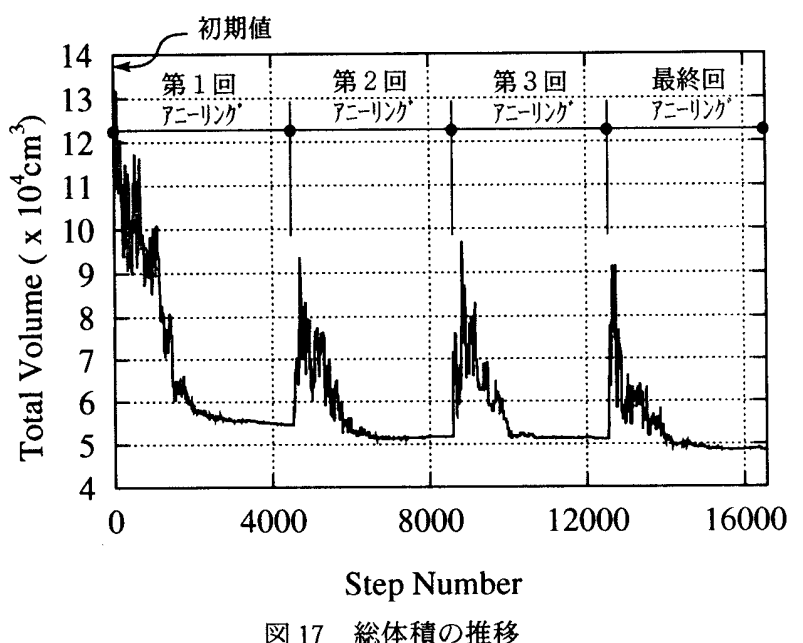

最終ステップでのトラス形状および総体積を示す。総体積を比較する と, Case Aが最も小さい。この結果より, 初期温度および温度更新係 数の違いが最終形状に及ぼす影響が大きいことが分かる。図15にCase Aのアニーリング過程におけるトラス形状の変化を示す。節点位置を 明確に示すため, 節点位置に○印を記した。トポロジーが変化してい く様子が分かる。

\section{2 例題 2 : 片持ち梁型トラス(Type-2)}

初期解として図16(a)に示す中心軸に対し上下に対称な片持ち梁型卜 ラスの形状最適化を考える。初期解における斜め部材は図中にnode と 示すように交点で接続する (例題 3,4 も同様)。W=600 cm, $H=150$ $\mathrm{cm}, P=98 \mathrm{kN}, R_{\max }=40 \mathrm{~cm}$ である。再アニーリングを行い, アニーリ ング回数は合計 4 回である。再アニーリング開始時の温度は初期温度 と同じとした。同(b),(c),(d),(e)図に各アニーリングにおける収束解を示 す。(b),(c),(d)図では節点位置を明確に示すため図 15 と同様, 節点位置 に○印を記した。図 17 に総体積の推移を示す。最終のトラストポロ ジーは Prager ${ }^{24)}$ が Michell ${ }^{25)}$ の理論を拡張して求めた “離散化された Michell トラス”と同一である。

本手法で得られる解は近似最適解であり,より厳密な最適解との対 応を明らかにするため, 得られたトポロジーのトラスに対して, 節点 座標を連続変数として準ニュートン法による最適化を行った。得られ た形状を図16(e)に破線で示す。本手法による解と良く対応しており， 本手法により精度の良い近似最適解が得られていることが分かる。

\section{3 例題 3 および例題 4 : 橋型トラス}

橋型トラスの形状最適化を考える。例題 3 として図 $18 に 1 つ の$ 節点 が鈶值荷重を受ける例(Type-1), 例題 4 として図 19 に 3つの節点が鈶 直荷重を受ける例(Type-2)を示す。節点移動の過程でトラスの対称性 を考慮する。 $W=400 \mathrm{~cm}, P=98 \mathrm{kN}, R_{\text {max }}=40 \mathrm{~cm}$ であり, 初期解にお ける構造物の高さは $100 \mathrm{~cm}$ である。図 18 において水平方向に $\mathrm{P} / 10$ の 水平力を与えるのは, 不安定なトラスの生成を避けるためである。い ずれも初期構造物に対し体積が半分以下のトラスが得られる。

\section{8. 結論}

一様部材断面積を有する平面卜ラス構造物のトポロジ一・節点位置 同時最適化問題に対する手法を構築した。例題を通じて本手法の特徵 および有効性を示した。得られた結論を以下に示す。

（1）短くなった部材の長さに対応して隣接部材の断面積を減じる 連続的トポロジー変化モデルとシミュレーテッドアニーリン グ法の併用は，本問題に対して有効である。

（2）連続的トポロジー変化モデルを 4 角形ユニットの存在を許容 するトラスに対して適用するときには, 節点座標だけでなく 部材の存在を表す変数を導入して, アニーリングの過程で確 率的に更新していく必要がある。

（3）アニーリングに対する温度管理が最終形状に及ぼす影響は大 きく，温度管理の方針について検討する必要がある。

(4) 初期解における節点数・部材数が比較的多く一度のアニーリ ングで最適解への収束が困難な場合には，アニーリング終了 後近接した節点群を結合し再アニーリングする，という操作 を繰り返すことにより最適解へ到達することが可能となる。

本論文では変位制約条件のみを考虑したが, 本手法は応力制約条件 や線形座屈荷重制約条件を考虑した問題にも容易に拡張できる。 


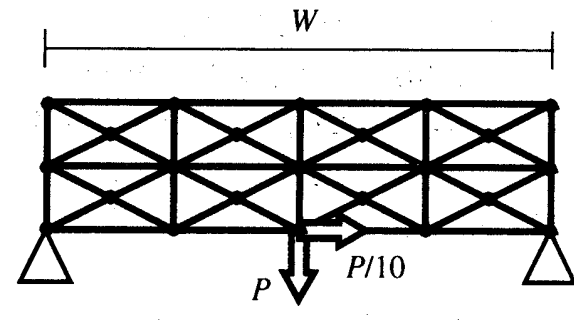

(a) 初期形状 (54 部材)；Volume $=4401 \mathrm{~cm}^{3}$

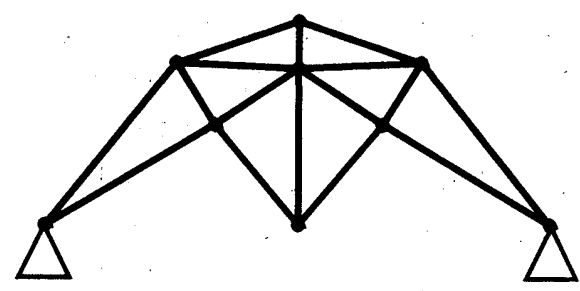

(b) 最適形状 (16 部材); Volume $=1597 \mathrm{~cm}^{3}$

図 18 橋型トラス (Type-1)

\section{参考文献}

1) U. Kirsh, Integration of reduction and expansion processes in layout optimization, Structural Optimization, Vol. 11, pp.13-18, 1996.

2) U. Kirsh, Optimal topologies of structures, Appl. Mech. Rev.,Vol.42, pp.223-239, 1989.

3) B. H. V. Topping, Mathematical programming techniques for shape optimization of skeletal structures, In: Shape and Layout Optimization of Structural Systems and Optimality Criteria Methods, G, I, N, Rozvany (Ed.); pp.349-375, Springer. Wien, 1992.

4) E. Sadek, Dynamic optimization of framed structures with variable layout, Int. J. Num. Meth. Engng., Vol. 23, pp.1273-1294, 1986.

5) M. P. Saka; Shape optimization of trusses, Proc. ASCE, Vol. 106(ST5), pp.11551174,1980

6) M. P. Bendsøe and N. Kikuchi, Generating optimal topologies in structural design using a homogenization method, Comput. Methods. Appl. Mech. Engng., Vol. 71, pp.197-224, 1988.

7) 坂本二郎, 尾田十八：遺伝的アルゴリズムを利用した最適トラス形態決 定法, 日本機会学会論文集 (A 編)，59巻，562 号，pp.156-161，1993.

8）大崎 純:遗伝的アルゴリズムに基づく不連続コスト関数を有する構造物 の最適設計法, 日本建築学会構造系論文集, 第464 号, pp.119-127, 1994.

9) M. Ohsaki, Genetic algorithm for topology optimization of trusses, Comp. and Struct., Vol. 57, No. 2, pp.219-225, 1995

10) P. Hajela and E. Lee, Genetic algorithms in truss topological optimization, Int. J. Solids and Structures, Vol. 32, No. 22, pp.3341-3357, 1995.

11) 三井和男, 登坂宣好: 遺伝的アルゴリズムの空間構造形態解析への応用 日本建築学会構造系論文集，第 484 号, pp.75-83， 1996.

12）大森博司，河村拓昌，鬼頭伸彰：遺伝的アルゴリズムを用いたトラスト ポロジーの最適設計 (その1，2），日本建築学会大会学術講演梗概集(B-1), pp.417-420, 1998

13) G. Reddy and J. Cagan, An improved shape annealing algorithm for truss topology generation, J. Mech. Design, ASME, Vol. 117, No. 2(A), pp.315-321, 1995.

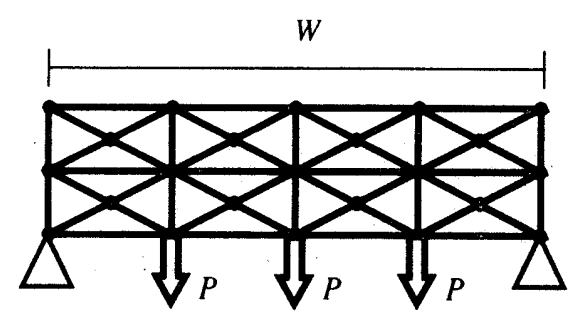

(a) 初期形状 (54 部材) ; Volume $=9065 \mathrm{~cm}^{3}$

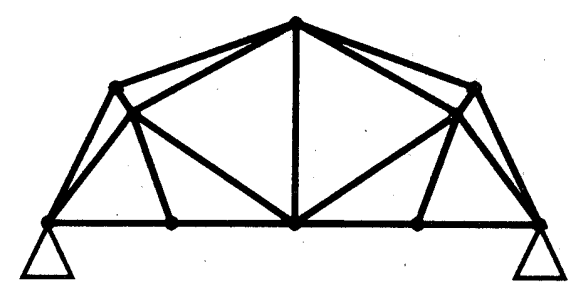

(b) 最適形状 (19 部材); Volume $=3774 \mathrm{~cm}^{3}$

図 19 橋型トラス(Type-2)

14) B. H. V. Topping, A. I. Khan and J. P. De Barros Leite, Topological design of truss structures using simulated annealing, Struct. Engng. Rev., Vol. 8, No. 2/3, pp.301314, 1996.

15) J. J. McKeown, Growing optimal pin-jointed frames, Structural Optimization, Vol. 15, pp.92-100, 1998.

16）宮下朋之,山川宏，エージェントによる最適設計に関する研究，第 3 回 最適化シンポジウム講演論文集, 日本機械学会, pp.243-248, 1998.

17) M. Ohsaki, Simultaneous optimization of topology and geometry of a regular plane truss, Comp. and Struct., Vol. 66, No. 1, pp.69-77, 1998.

18) M. Ohsaki and H. Tagawa, Genetic algorithm for simultaneous optimization of topology and geometry of a regular plane truss, Proc. OPID 97, Tokyo, Paper 121, JSME, 1997.

19) A. R. Díaz and M. P. Bendsøe, Shape optimization of structures for multiple loading conditions using a homogenization method, Structural Optimization, Vol. 4, pp.17-22, 1992.

20) S. Kirkpatrick, C. Gelatt and M. Vecchi, Optimization by simulated annealing, Science, Vol. 220, pp.671-680, 1983.

21) N. Metropolis, A. Rosenbluth, M. Rosenbluth, A. Teller and E. Teller, Equation of state calculations by fast computing machines, J. Chemical Physics, Vol. 21, No.6, pp.1087-1092, 1953.

22）B. E. Rosen, 中野良平；シミュレーテッドアニーリングー基礎と最新技 術一, 人工知能学会誌, Vol. 9, No. 3, pp.365-372, 1994.

23) L. Ingber, Very fast simulated re-annealing, Math. Computer Modeling, Vol. 12, No. 8, pp.967-973, 1989.

24) W. Prager, A note on discretized Michell structures, Comput. Meth. Appl. Mech. Engng., Vol.3, pp.349-355, 1974.

25) A. G. M. Michell, The limits of economy of materials in frame structures, Philosophical Magazine, Vol.8(47), pp.589-597, 1904.

26）田川浩, 大崎 純 : 連続的卜ポロジー变化モテルおよびシミュレーテッド アニーリング法を用いた平面トラスのトポロジー節点位置同時最適化法, 第3 回最適化シンポジウム講演論文集，日本機械学会, pp.225-230, 1998. 